ÉGYPTE monde arabe

\section{Égypte/Monde arabe}

1| 2005

Le shaykh et le procureur

\title{
Authority, arbitration councils and civic society
}

\section{Hans Christian Korsholm Nielsen}

\section{CpenEdition}

\section{Journals}

Édition électronique

URL : https://journals.openedition.org/ema/1899

DOI : 10.4000/ema.1899

ISSN : 2090-7273

\section{Éditeur}

CEDEJ - Centre d'études et de documentation économiques juridiques et sociales

\section{Édition imprimée}

Date de publication : 30 juin 2005

Pagination : 187-206

ISSN : 1110-5097

\section{Référence électronique}

Hans Christian Korsholm Nielsen, « Authority, arbitration councils and civic society », Égypte/Monde arabe [En ligne], 1 | 2005, mis en ligne le 08 juillet 2008, consulté le 07 juillet 2022. URL: http:// journals.openedition.org/ema/1899 ; DOI : https://doi.org/10.4000/ema.1899

Ce document a été généré automatiquement le 7 juillet 2022.

Tous droits réservés 


\title{
Authority, arbitration councils and civic society
}

\author{
Hans Christian Korsholm Nielsen
}

1 When dealing with traditional institutions of arbitration, questions about the relationship between concepts such as authority, power and persuasion, or the formation and reproduction of these, continue to be the most intriguing and constantly recurring. In this paper, I argue for a position where the concept of authority should be analysed as a separate entity, radically different from power and persuasion, but, in the actual operation of the arbitration councils under discussion, interwoven and interacting with, or in a constant tension with, the other forms of social control. Through this analysis, I hope to present one explanation for the ability of the popular, non-state reconciliation councils found in Upper Egypt to adjust to conditions of modern life, and thereby to give a plausible reason for recognising them as a part of civic society. ${ }^{1}$

\section{Notes on the concept of Authority}

2 The intriguing nature of the concept of authority may be ascribed to the difficulties that arise when trying to separate it from other concepts of social control, such as force, power, legitimate power, persuasion, or logical argument, compared with the commonsense feeling that it obviously differs from these, as one clearly senses through the insightful description of authority made by Hannah Arendt:

Its hallmark is unquestioning recognition by those who are asked to obey; neither coercion nor persuasion is needed. (A father can lose his authority either by beating his child or by starting to argue with him, that is, either by behaving to him like a tyrant or by treating him as an equal). (Arendt quoted in Friedman 1990:63/64).

While Arendt's description is disturbingly obvious, the problems occur when moving from such descriptive statements to defining an analytical concept, when specific delimitations need to be made and the usefulness of defining the concept should be stated. Why is authority not just a sub-category of power, as many would argue? 
Another important point is that one must insist on a definition that ensures that not only those people or that entity having authority are included, that is, it should take into account that authority is a relationship between someone or something which has authority and someone or something which submits or defers to that authority, and that it is not just a capacity connected with or ascribed to someone. Those who defer are in many situations well aware of doing so, and deliberately submit either because they may gain some benefit from doing so, or because they recognise that the one submitted to has an insight that makes the submission worthwhile. At the same time, it is important to bear in mind that those submitting may also influence the authority in more subtle ways, just as the son mentioned by Arendt may influence the father.

4 Another important issue should be to avoid concepts that are inscribed in some kind of evolutionary schemata, or formulations where different forms of authority are attached to specific historical eras. Writers about authority often refer to Weber's threefold ideal classification of claims to legitimised authority:

- the Rational grounds: resting on a belief in the legality of the enactedrules and the right of those elevated to authority under such rules to issue commands (legal authority);

- the Traditional grounds: resting on an established belief in the sanctity of immemorial traditions and the legitimacy of those exercising authority under them (traditional authority);

- the Charismatic grounds: resting on devotion to the exceptional character of the individual person, and the normative patterns or order revealed or ordained by him (charismatic authority) (Weber, 1978:215).

5 As is quite clear, however, Weber does not talk about actual authority, but is describing ways of legitimating power, which is quite different from authority. Another problem with his definitions is that they are inscribed in a very specific evolutionary story, where legal authority is something that developed in the modern age, and more specifically is a concept derived from experiences with Prussian bureaucracy.

Although the formulations of Arendt succinctly describe the question raised, her stand is also very much inscribed in evolutionary thinking. As the title of one of her most famous articles ("What Was Authority") indicates, Arendt finds that authority is a concept that, together with religion and tradition, has lost its meaning in a modern secularised world. She is of the opinion that the concept grew "out of the Roman experience of foundation and was understood in the light of Greek political philosophy" (Arendt, 1958:110). It was taken over by the church, which according to Arendt was the carrier of the Roman legacy, but because of the declining influence of Christianity in the modern world, the concept likewise lost its position or meaning.

7 Although such grand histories are not the issue here, it still seems questionable to reject the possibility of using the concept of authority in modernity, or, for that matter, to leave out the use of "legal-rational" forms of authority when analysing other places or other times. What we are looking for, in fact, is a smaller concept, suitable for a more pragmatic social analysis. One author who has developed such a concept is Richard B. Friedman, in his essay "On the Concept of Authority in Political Philosophy" in 1990; ${ }^{2}$ and in order to define some central elements of the concept of authority I shall rely heavily on this.

8 A main issue for Friedman is precisely that authority is something that differs from, but is in the same family as, power, persuasion, force, etc., or, as he writes, it is a part of a network of influence terms, but not subsumed under any of the others (Friedman, 
1990:60). Authority is notably not a species of the genus "power", nor is it something dependent on or secondary to power, but belongs to the more inclusive category of social control or influence.

9 It should be noted at the outset that although Friedman clearly defines why authority stands in opposition to the other terms creating the field of social control, he is not very clear about the relationship between these, and the reader is left with very little knowledge about what happens when moving from the discussion of an ideal concept to a world in which authority is embedded. Here Skalník's reflections concerning the "tension" between authority and power, coercion, etc. may be useful. He finds that there is a struggle between these two, which to him are fundamentally opposed concepts and "which relate to mutually exclusive 'ideal types' of arrangements of public affairs" (Skalník, 1999:164). In the real world, he observes that the tension or struggle between the two concepts is extremely complex, but the overall quality of the arrangements where authority has the upper hand has proven to be "fundamentally better", and that much political struggle is actually concerned with reaching the right balance or mix between the two. While not reducing it to a mere question of a moral discourse, this means that the arrangements have been "more durable and truly accepted" (Skalník, 1999:164). This refers to the general observation that naked power, or, one may add, decisions based on naked power, rarely survive, and reference is made to the dictum about the difficulty of sitting on bayonets (ibid.).

10 I shall present some of the relevant definitions found in Friedman's essay, first of all to give a background to the argument that the reconciliation councils found in Upper Egypt rely on a specific mix of these elements, thus allowing one to say that they qualify as part of modern civil society. One of the central distinctions in Friedman's work is between authority based on being in authority and being an authority. To some extent this is similar to the Weberian distinction between legal-rational forms of authority and charismatic authority, ${ }^{3}$ although with the significant difference that the idea of a historical development from one to the other, and the importance to modernity of the introduction of a "in-form" of authority, is not a central aspect of Friedman's writing, and nor does he recognise legitimate or legitimised use of force as a form of authority.

11 If we stay with Arendt's proposition: The father may have a right (even granted by the state, as was the case with the revelsesret ("right to castigate") in force until a few years ago in Denmark) to use force to compel his son to follow a command, but he will certainly not be in authority if he does so.

Persons may thus be in authority and occupy a position or status that entitles them to make decisions that are binding on other people, or they may be an authority, and thereby entitled to be believed because of personal qualities; that is, they are experts, priests or parents, while on the other hand, legislators, judges and generals who are in authority have authority over conduct.

13 The recognition or deference by those submitting to authority is discussed by Friedman under the heading surrender of private judgement, ${ }^{4}$ something that is essential to an understanding of authority in this sense. This notion should convey the idea that obeying a command is done "simply because it comes from someone accorded the right to rule, the subject does not make his obedience conditional on his own personal examination and evaluation of the thing he is being asked to do." Or, seen from the perspective of those issuing the authoritative command, they do not have to "... offer 
reasons on behalf of what one has prescribed as a condition of being paid obedience" (Friedman, 1990:64). One could say that the source of the claim to authority is of interest, not the content of what is said.

Another important distinction is thereby alluded to, that of separating a piece of advice or counsel from an authoritative command and authority: whether you would follow a piece of advice is conditional on your own judgement of the content of the advice given, while the command is followed, not because of what is said, but because of who says it. The concept of surrender of private judgement needs to be qualified, because it raises the obvious question of whether there are limits to this surrender. Are we talking about blind obedience, or are the subjects able to challenge the validity of the commands of the authority? Is there any possibility of submitting and at the same time holding personal opinions or views?

According to Friedman, there are a number of possibilities; (a) surrendering to the authority without evaluating the utterances (commands) at all, because they are automatically understood as being of unchallengeable normative validity; or (b) the case where a person does judge, but submits anyway, irrespective of his own judgement. "In the former case what is surrendered is judgement itself... in the latter it is choice which is suspended: the subject desists from acting on his own judgement even though he may 'privately' dissent from the authoritative utterance" (Friedman, 1990:65). These options are - in a strict sense - valid only for conduct, because authority over beliefs calls for some kind of "internal assent", whereas the notion of acting in conformity to commands of authority allows for dissociation of thought and action, with the consequence that there is "unquestioned obedience and internal assent" confronting an "external conformity".

What have been presented here are obviously cases where the subject refrains from questioning the justification, which suggests some kind of conscious act, or at least the possibility of it. Against this, there are some cases where the subject does not refrain from questioning the justification of the authority, but where it does not even occur as a possibility to the subject that questions could be asked: the subject has no option of standing back and looking at his/her world and questioning the authority. This is what Friedman calls "traditional authority" or "customary authority (Friedman, 1990:73). ${ }^{5}$ The rules are self-evident and self-justifying; or it could be said that the subject does not abstain from private judgement, but that there is an absence of the recognition that one has the capacity to judge. ${ }^{6}$

17 The distinction between being in and an authority has more consequences than merely defining what characterises these fundamental forms of authority, because they are based on two very different forms of justification or reason for being deferred to. The justification for having someone in authority is based on the idea that he has to remedy a problem; that is, the cost of following one's own judgement may be chaos, for example in the local community. There is a reason for complying with the commands, and it appears reasonable to those who submit or surrender to the authority and sacrifice their own judgement. At the same time, the ways of deciding who is in authority should be accepted: i.e. the oldest in the lineage, someone elected, chosen by lottery or by some other means. Friedman summarises this as:

So the point of having someone "in authority" is to be discovered by considering what would happen if each person insisted on making up his own mind as a condition of coordinating his actions with his fellows. From this perspective, the authority relationship will then appear as an elaborated contrivance designed to 
achieve agreement at the procedural level in face of disagreement at the substantive level ... (Friedman, 1990:78) ${ }^{7}$ pertaining to the person; his claim to be obeyed is simply based on the fact that he is put in authority according to established procedures, and what he produces is a decision to be followed - not a statement to be believed - so that what is at stake is not, therefore, some kind of internal assent as a prerequisite for submitting to this form of authority. This differs radically from the justification of an authority, as Friedman writes:

Here the justification for deferring to some person is that he is thought to have special knowledge, wisdom, or insight or to be the recipient of a revelation or unique experience not available to other men. What is essential to this sort of authority is that something be accessible to one person that is inaccessible or less accessible to others, whether this special access involves expertise, learning, singular experience or skill, revelation etc. (Friedman, 1990:80)

We are not talking of a decision to be followed, but of a statement to be believed - the opposite of what characterises the relationship between those submitting to the person in authority - and some kind of internal assent is necessary for this response. In comparing the two, one could say that in the case of an in authority position, the system is logically prior to the person, and in case of an authority relation, the person and his/her characteristics are the prerequisite for the authority to be exercised successfully. To this, it should be added that they also differ when one looks at the presuppositions they are based on, where deferring to an authority presupposes a recognition of inequality between the parties, but deferring to someone in authority does not imply an inequality antecedent to the authority relation itself; on the contrary, it implies some sort of equality that is recognised by both parties. That is, it implies that both parties have accepted the presumption that a consensus may not be reached if someone is not put in authority. Of course, this does not mean that people do not accept the differences among themselves or that they are unequal in insight, education, etc. (Friedman, 1990:82).

This is central to the following, because in principle there is nothing that demands of the in authority relation that there be a prior hierarchical relation between the two parties (although the authority relation is of course hierarchical in itself). ${ }^{8}$ But again, it should be noted that on an empirical level - taking more than the actual authority relation into account - those in authority are often placed in a dominating position prior to the in authority relation, through their lineage, etc. This has nothing to do with the authority relation itself, but is related to power, persuasion, etc.

21 For Friedman, the question of inequality and the discussion presented here is the first presupposition for understanding what the concept of an authority contains, but behind this is what he calls the second or "epistemological presupposition", by which he means that:

... [before] a person should defer to the superior knowledge of insight of another person [it is presupposed] that such knowledge or insight is in principle available at least to some humans. And, in turn, the person who defers must share with his authority this same "epistemological" framework which defines what sort of things are accessible to the human mind or to human experience, even though he is himself debarred from that knowledge or experience through lack of the requisite learning, wisdom, grace, revelation, opportunity, etc. (Friedman, 1990:83) 
In other words, an authority presupposes a common moral ground or, as mentioned, a common "epistemological framework". This has consequences for the understanding of the writings of, for example, Arendt, who was concerned with the disappearance of authority in the modern age. What she is lamenting is the disappearance of a relationship of authority that is basically an an authority relation, on which Friedman comments:

... the dissolution of moral authority... applies strictly to the case of being an authority because it is here only that authority need be a spokesman or interpreter of a prior system of beliefs. But someone who is in authority is not necessarily an authority on anything: his decisions do not have to be presented as authoritative expressions, deliverances, or interpretations of logically prior principles. On the contrary, it is precisely the key point about the concept of "in authority" to be dissociated from any background of shared beliefs" (ibid., 1990:84).

The "disappearance of authority" in modern society is, in other words, a movement from a society based on common moral grounds towards one where other forms of authority (i.e. in authority relations) are more appropriate. In that sense authority does not disappear, but the balance between these forms of authority changes, and the an form may be said to be relegated to more localised forums such as religious congregations, universities, clubs, etc.

Besides the two central discussions concerning in and an authorities and the concept of surrender of private judgement, a third concept is treated at some length by Friedman: what he calls the mark of authority. In order for any authority to be recognised, there must be some public way of identifying it. Friedman finds this in the way the communication takes place between those submitting to authority and the authority itself, and contends that a command or authoritative communication contains both a substantive proposal that describes what the one deferring is supposed to do, and also something extra that identifies the one who is speaking (Friedman, 1990:69-70). This is seen as "a logical requirement of deferential obedience" (ibid.:69), because if this extra something is not contained in the communication, those deferring are left to evaluate the message - the substantive proposal - and we are then back at the situation where we are not talking about authority, but about advice or logical argument.

This "extra" in the communication is what is traditionally called the mark of authority, that by which the authority is identified. This may be anything from figures of speech, or credentials, to office, social status, religious claims, miracles, wealth, or tradition and customs.Because these marks of authority should be recognised, those submitting and those issuing commands must be inscribed in some kind of common moral, cultural or linguistic universe. Friedman states:

Authority thus involves a form of influence that can only be exercised from within a certain kind of normative arrangement accepted by both parties. Therefore to explain how one man can exercise authoritative influence over another always calls for an explanation of the existence (acceptance) of the arrangement within which the parties conceive themselves to be embraced" (Friedman, 1990:71)

This is central, both because the ability of the authority to make people abide by the commands and the deference to authority become something that is dependent on context, since authorities are not so everywhere or at all times, and because one could say that they should be related to some kind of common social or normative field where the commands issued are accepted as authoritative commands or statements. ${ }^{9}$ 


\section{The Appointed reconciliation councils in Upper Egypt}

I have presented these key elements from Friedman's essay because some generally useful insights may be gained from them, and because I often find that too little attention is paid to what the concept of authority may actually contain. It seems too simple just to refer authority to a secondary place under power or coercion, or a discourse of power, etc., or at least this would not do justice to the disturbing obviousness of the passage by Hannah Arendt. However, my main intention is to try to demonstrate some developments in the ways non-state reconciliation or arbitration councils are arranged in Upper Egypt, which point towards changes in the authority relations and thereby give an indication of the ability of the councils to adjust to demands from the parties involved.

At issue is that the disputing parties or those arranging the reconciliation, that is, the councils, have had an ability to adjust or have been forced to do so, and consequently have been transformed along lines where the authority structures are more "democratic". This is possibly an adaptation to a general situation where those having disputes settled by the councils are people who, among other things, through the spread of mass education have gained another perspective on these traditional ways of settling disputes, or they may be said to demand more, or at least other, ways of dealing with disputes than in the past.

This may also exemplify why civic institutions are carving out more space for themselves in contemporary Egyptian society. Reconciliation councils or reconciliations cannot depend only on powerful individuals enforcing arbitrary solutions; neither can solutions reached through the sheer use of force be durable in a world where traditional forms of social control are losing their meaning. Although elders still hold a large share of the power in Egypt, their position is being challenged by the young and educated and by the rapid changes in society. The traditionally localised fields of social control are losing importance, because both young and old travel outside the region in pursuit of jobs and education, and many of those submitting to the councils seem to want to have their own say, and therefore the procedures by which councils are appointed have to adjust to these new demands. ${ }^{10}$

Non-state dispute settlement has a long tradition in Egypt, both in rural areas and in the cities. ${ }^{11}$ Often those in charge of settling disputes have been powerful and charismatic locals, who through their position in the local communities, or by means of their personality, have been given the role of arbitrator in local disputes. The popular image of the arbitrary decision made by a village headman - 'umda - springs to mind. The 'umda was a central figure in the legal field, and was expected to enforce state law and secure order through his corps of guards, along with his other duties such as tax collection and, in Upper Egypt, ensuring that men were registered for drafting at a suitable age and were available for the forced common work in the maintenance of the dams, etc. Among the better-known obligations of the "umda was the duty to show hospitality to travellers, sustaining a "guesthouse", and settling disputes through personal intervention. Today this institution has lost much of its importance because of the expansion of the police, and the position is officially abolished in areas where a police station is found. But in those areas where it still exists, the 'umda is most often involved in arbitrating disputes, and this may also be the case even in places where the 
position has officially been abolished. Often the families that once held the position still have political or economic influence, and are sought after as arbitrators.

Although few detailed descriptions of the customary law institutions in earlier periods are available, Khalifah (Khalifah, 1940), who published on the Ababda tribe of the Eastern Desert (which today have mostly settled in the Nile valley around Edfu and Daraw), provides some information about the judges of the Ababda. These were the elders of the tribe and they administered 'urf, which Khalifah describes as a substitution for law (qânûn) among the inhabitants of the Eastern Desert. He enumerates several rules, dealing mainly with the size of fines and compensations to be paid for damage or injuries inflicted on animals, pasture, wells, trees and humans: fines for adultery, for lack of submission to orders given by elders/shaykhly members of the tribe, and compensations for the breaking of teeth, legs, hands - and for murder. In the latter case, the compensation demanded is one hundred camels aged three years or more. One clause states that "If one man beats another, he who has beaten should pay compensation to the one beaten as decided by the judges, and if the party hurt is injured the culprit must pay for the treatment." Here the term "judges" refers to the elders and the experienced leaders of the tribe. However, no references are made to their being appointed: their position is based on their seniority and position within the tribal structure (Khalifah, 1940: 23-24).

Other such personalities have traditionally been - and still very often are - religious leaders, such as shaykhs heading the different Sufi orders, or who in other ways have been able to establish themselves as local leaders through their religious involvement. Local politicians are also important as arbitrators, either as members of the different local councils, or as representatives elected to national bodies such as the majils alsha'ab or the majlis al-shurah. Election to one of these often implies that the person should act as an arbitrator when conflicts occur within his constituency. It is most important, however, to emphasise that there are in Egypt many variations in how arbitrators are found and selected. It is equally important to emphasise that there are numerous styles of arranging and carrying out arbitration, as well as differences in the form of meetings dependent on the arbitrations, and in the way councils are appointed or how they act towards the parties they are trying to reconcile - and, for that matter, also in the kinds of power or authority that are vested in the roles of arbitrators.

This is still the case today in a district like Edfu District in Aswan Governorate. Here there are numerous variations, and sometimes even those who are active in this field seem to be developing their own styles, and choosing particular ways for dispute settlements to be arranged. Some arbitrators accept that the disputants are selfconfident and have a very combative style when approaching a council or arbitrators, while others - especially older religious leaders - may not be ready to engage in arguments with assertive younger people, and in cases where these elders are leading or participating in the councils the whole session may take a different turn.

Differences also depend on the nature of the dispute, on what is disputed, or on the level of violence involved; there seem to be at least three different categories for classifying local disputes in the Edfu region. First, there are the very localised disputes, where the disputants are close kin - that is, it may be a dispute between spouses, or else one that has limited significance, or has not (yet) reached a level of severity or violence where it is seen as endangering the general peace of the community. Such conflicts are most often settled by groups of men or individuals who, on their own 
initiative, choose to intervene in the dispute in order to find a solution, or they may be solved by one of the standing reconciliation committees found in some villages, as outlined below. A second level may include disputes over property - primarily land but it also includes conflicts over inheritance, or outbreaks of violence on a lesser scale, such as fights or disputes that contain some element of violence between the parties, but where the cause of the dispute is otherwise difficult to pinpoint. It is this level of conflict that I shall discuss here, leaving out both the first mentioned and also the third level, which contains the settling of feuds and the reconciliation of families between whom killings have taken place.

This attempt to develop a classification of the conflicts and of the institutions involved in settling them is dependent not only on the nature of the cases, but also on the fact that the men engaged in solving them belong to a large extent to a different stratum of arbitrators, and the institutions - the councils arranged in connection with the settling of the disputes - differ radically in their form and methods. ${ }^{12}$

The settling of disputes on the first level is without doubt the most common, but at the same time the one that receives least attention. Taking responsibility for trying to solve these kinds of dispute is such an ordinary and commonplace act that it almost goes unnoticed, and one can be sure that if a brawl occurs in the market or lanes of a village in Upper Egypt, somebody will very likely try to intervene, and when minor disputes arise within a neighborhood, or between spouses, a few older men will probably approach the parties in an attempt to calm them down or find a solution. This is so widespread in Upper Egypt that, together with the more elaborate forms of dispute settlement where councils are appointed (described below), it constitutes one of the fundamentals of society. To a considerable extent, the whole idea of reconciling or arbitrating disputes in reality takes up much more space and time than the outbursts of violence that tend to receive the attention, especially outside the region. For example, in the much-publicised case of Bayt 'Alam, news about the feud and the killings rapidly reached the media, and was referred as a product of the "infamous clan system" of Upper Egypt. But what rarely attracts media attention are the much more important and widespread efforts carried out by numerous people to prevent or contain eruptions of violence and the spreading of disputes within Upper Egyptian society.

Although the more or less anonymous interventions made by people in their neighbourhood may be the most common form of dispute settling in Upper Egypt, interventions at the second level are also common. In an area such as Edfu District there are often one or two arranged every week, while conflicts at the third level of settling feuds are very rare, and the councils dealing with these are arranged only once or twice a year. The councils that solve disputes over land, water, inheritance or lowlevel outbreaks of violence - the second level - constitute the backbone of the whole scene of dispute settlement in the northern part of the Aswan and the southern part of Qena Governorate. They are the councils involving most people as arbitrators and council members, and they solve the vast majority of disputes at this level. ${ }^{13}$ These councils are known as majlis al-sulh or majlis-tahkim - reconciliation or arbitration councils. They are arranged by the older men of the villages and towns, and are in principle organised independently from the official legal system.

As mentioned, when disputes occur it is usual that neighbours try to find ways of resolving them, but if they do not succeed they may try to get the parties to agree to have the dispute investigated and settled by an outsider. Where this is accepted, it is 
common that the neighbours involved contact one or more of the elders who are known to arrange dispute settlements, and ask him or them to try to mediate. If the elders obtain the acceptance of the disputants to seeking a solution, then they frequently suggest that a council is appointed. These councils consist of a varying number of men, the total often reflecting the seriousness of the dispute: the more the members of the council, the more severe the dispute. In theory, a number of rules are followed in the appointment of council members. Among other things, these include that council members must be accepted by both the disputing parties, and ideally the appointment also reflects the logic of tribal segmentation found in this area, where tribal organization is dominant. In short, the council members are often chosen from tribal sections other than the one to which the disputants belong, and in the case where the disputants are themselves tribal sections, or at least referred to as such, those intervening and arranging the councils are from other tribal sections or other tribes.

In practice, what is paramount is that those appointed are not related to the disputing parties, so that they cannot be accused of having a direct interest in the case, and this concept of the council's impartiality is most important. In addition, a group of men who have more or less specialised in working as arbitrators are most often involved. It consists of elders who have a reputation for their ability to settle disputes and arrange councils, and for their knowledge of the tradition ('urf), which is seen as the foundation for the solutions, even though it is not written down and does not contain specified principles. In reality, the solutions reached are based on the negotiations that take place between the council and the disputing parties, with a reference to precedents, and a fundamental belief that the solution should be seen as appropriate according to the cultural or moral framework, and that it is "fair". One way of assuring this is that the solution reached by the council is publicly announced to the crowd of men invited to witness the final stage of the arbitration. The solution is in principle arrived at through a combination of negotiations between the council and the disputants, and a secret evaluation of the case by the council; during the final stage of the deliberation the council will isolate itself in order to discuss the case and reach a unanimous agreement.

In the earlier part of the dispute-settling process, when the disputing parties have agreed to the proposed members of the council, it is then often authorised by the parties. This agreement is central to the argument and is a development that seems to have taken place in recent decades. An authorisation can be granted by issuing a document called a mahdar tafwid (statement of authorisation), which is completed before the case it taken up by the council, and often a specific meeting is held where this document is written and signed. But this is the ideal situation, and it is frequently the case that the document is written just before the final meeting starts, or it may even be incorporated in the final document, the mahdar al-sulh or mahdar al-tahkim (statement of reconciliation or statement of arbitration), which is issued when the council has completed its deliberations. This final document contains paragraphs describing the case as it was understood by the council, and is based on an inspection of the site of dispute, documents pertaining to the case, statements made by the parties and other people involved, and also the questioning of the parties and of witnesses, which takes place on the day of the final meeting of the majlis al-sulh.

41 An example of an authorisation is the following, issued on the 26 December 1991: ${ }^{14}$ 
Bism Allah al-Rahmand al-Rahim

Mahdar tafwid

It is today Thursday, the date is 26/12/1991 we are in the madayfa of al-'Amrab in the hamlet of al-Buhayrah, Edfu District, Aswan Governorate, to arrange for the mahdar al-tafwid between all of the al-Kamilab who are the first party, and the alKarajab, the second party. And through this the two parties have given authorisation to the council consisting of the following al-Hajj Muhammad Ahmad Muhammad 'Asi and Muhammad Ahmad al-Saman Jad and Ali Ahmad Muhammad and Shadhly Ahmad Khalil and Nasir Ahamd Ali Hassan and Mursi Mahmud alTayyib and Sa'id Abd al-Basit 'Awwad Allah, to do what the council may find proper and what is in consent with and acceptable to the two parties.

And Allah is Master of fortune.

First party

Second party

As can be seen, this document is issued in the guesthouse (madayfa) of the tribal subsection of the 'Amrab, which is a section of the 'Ashabab branch of the 'Ababdah tribe, and during a special meeting taking place before the final settlement meeting. The dispute is between two tribal (sub)sections, the Kamilab and the Karajab, and the authorisation is valid for the whole of the two groups, that is, they are collectively responsible for the authorisation and for accepting the solution reached. What is noteworthy is that it is not found necessary either to say why the council is authorised, i.e. that there is a dispute between the two parties, or what the dispute is about. It is also interesting that no fine is mentioned for not accepting the solution found by the council, or for not adhering to it or to the authorisation. These points are frequently specified in the documents. The council authorised to look into this dispute consists of seven men from the Edfu region.

In the next example, the object of the dispute is specified (but not, of course, its cause something the council will settle at the final meeting, taking into account the evaluation of liability and the solution chosen), together with a fine.

Bism Allah al-Rahman al-Rahim Mahdar tafwid It is today Friday, the date is 26/2/1988 in the residence and house of al-Hajj Sayyid Na'im 'Abas, Edfu Qibli, Edfu District, Governorate of Aswan and present is the first party Yasin Hamid Yasin, second party Mahmud Husayn Mahmud Ahmad Razaq who are authorising the council consisting of al-Hajj Sa'id Abd al-Basit 'Awwad Allah and al-Hajj Ahmad Muhammad al-Saman and al-Hajj Yasin Sa'ad Muhammad and Ahmad Abd Allah Muhammad al-Sadiq and Muhammad Ali Amin and Ahmad Mustafa Hassan and Muhammad Ahmad Yasin and al-Hajj 'Awwad Allah Bakri Uthman and Ibrahim Yusuf 'Amr and Ahmad Muhammad Nail to settle the existing dispute between us concerning a piece of land measuring 8 qirat and $5 \mathrm{sahm}$, situated in the hud [basin] al-Nakhl number 9 , in section 48 . We have authorised the council mentioned above to find what is proper to solve this dispute. And this is an executive obligation. And he who breaks the decisions of the council by not following the obligations - Allah forbid - must pay an economic fine of the amount of 10,000 Egyptian pounds. And this is hereby the authorisation. And Allah is Master of fortune. First party Second party Yasin Hamid Yasin Mahmud Husayn Mahmud

Note that this time the disputing parties are individuals. To some extent, individuals are accountable for actions by the members of their households as well, or for others who may support them, and also for the dispute not being taken up again after it has been settled. However, the council will have a weak case if it tries to make the signatory parties pay the fine, if they are not clearly responsible for a reinstigation of the dispute.

This time the meeting arranged for the signing of the authorisation is held at a private home (in Edfu Qibli). This does not mean that the final meeting (the majlis al-sulh) is 
going to be held here, and it will most likely take place at a guesthouse. That the signing of the authorisation is happening in a private home is possible because this case has only two disputants. As can be seen, the conflict is over a specific piece of agricultural land of 8 qirat and $5 \mathrm{sahm}$. The fine that a party may be forced to pay if it does not accept and follow the council's solution is quite substantial: 10,000 Egyptian pounds in 1988.

There are other possible fines: in some cases the disputing parties have to hand in blank cheques to the council, and it is then up to the council to decide the amount of the fine and what the money will be used for. A third variation is that the council specifies that if one party breaks with the decision taken by the council, the other party has the right to take the case to the local official court, which for these cases is the district court of Edfu. This variation shows that although these councils are arranged by locals, and in principle are not connected to the official legal system, there is a certain interaction between the two systems, and even if the councils are seen locally as belonging to an arena that is distinctively different from that of state courts, bureaucrats, lawyers and judges, and one where Arabic, Islamic and tribal values are central, there is still a an overlap between one and the other.

In this connection it is important to mention that sometimes the documents contain clauses that specify that if any of the parties have taken the same case to the local court, or submitted a complaint to the police, then these should be withdrawn, or there may be a clause underlining that the solution reached by the council should be valid both in regard to the authorities and the tradition ('urf). In these cases, the authorisation may be said to have the function of delimiting a particular legal field, of specifying the jurisdiction of the councils, thereby ensuring that what might otherwise constitute an uncertain situation of competing fields of legality is dealt with, at least for a while.

As can be seen, there is a wide range of implications in having the disputing parties sign the mahdar tafwid, whether pertaining to the jurisdiction of the councils, to the interaction between state institutions and these popular councils, or to the dispute process (because the signing of the document limits the possibility of further negotiation by the disputants), etc. But the central aspect is the way in which the council is appointed, and how those appointed are vested with authority.

\section{Dispute Settling and NGOs}

As an example of other new developments in dispute settlement in Upper Egypt, there has been a growing interaction between the long-established reconciliation processes and new forms of social organization. Some have aligned themselves with organisations belonging to the area of modern civil society, those favoured by donor organisations and referred to when discussing the state of civil society in Egypt. In many areas of Upper Egypt, different NGOs are taking care of specific issues, or focusing on specific problems occurring in the villages and towns. Also widespread are the Community Development Organisations (CDAs). These not only target a specific topic, but through a number of subcommittees may be involved in a wide range of projects and issues in the villages. They may have committees that focus on women's issues, arranging sewing or literacy classes, or a particular committee running a kindergarten in the village, or a committee working with water and sewage, or they may run small loan funds, such as 
revolving funds intended to help villagers upgrade their water and sanitary installations, and they may also have a standing reconciliation committee - a lajnah musalaha. These last committees constitute an ordinary subcommittee under the CDA board, and are in principle organised along the same lines as the other types of committee.

For example, the village of al-Daqadiq in Edfu district has a reconciliation committee consisting of five members. In principle, the members are selected so as to represent the different tribes and tribal sections found in the village. Of these five members, some are elderly gentlemen who are pensioners, others are full- or part-time teachers at the local al-Azhar primary school, one of whom is the nephew of the 'umda of the whole of the village area. The way they are appointed is through being active in the CDA, and one of the five also holds the position of chairman of the CDA's board. The connection to the CDA not only has an influence on who the members on the committee are, but on its judicial status, because it can only intervene in disputes occurring in the village, or in the area covered by the local CDA. Disputes that involve persons from different villages may not be solved by these councils, and are referred to another council, such as the traditional ones mentioned above. That is why the nephew of the 'umda, and not the village headman himself, is part of the committee: the headman is involved in the circuit of councils spanning a larger area. This does not mean that the councils exist in isolation: meetings are sometimes held with similar councils in neighbouring villages, in order to find ways to settle disputes that involve participants from both villages. But in principle, the jurisdiction of the councils is limited to the area covered by the CDA. There are also other limits: if a dispute reaches a certain severity, the committee is regarded as not strong enough to solve the problem, and will have to rely on the other, types of council described above.

51 In general, it can be said that as a result of being appointed by the elected boards of the CDAs, the reconciliation committees acquire a status different from that of traditional arbitrators: they are the appointees of an elected board, seen as representing a specific area. This does not, of course, say anything about whether the CDA in a specific case is representative of a village. In certain cases the CDA represents only some of the tribes living in an area, and it is notorious that the tribes known to be marginalised and traditionally limited in their choice of occupation are most often those not represented on CDA boards, nor even members of their community organisations. In principle, however, this does not change the status of the reconciliation committees, which are as much a part of civil society as the boards and CDAs appointing them. is certainly part of it - Norton, 1999); nor should they be seen as a simple reaction to the incapability of the official legal system, or a reaction caused by the widespread popular mistrust of that system. These councils are an integral part of local communities and are invested with numerous layers of political and symbolic meaning. They should therefore primarily be analysed not as a reaction to something, but as an important, integrated component of Upper Egyptian society (see Nielsen, forthcoming). But if one looks at the specific forms of authority created through the ways a particular group of councils are organised, the introduction of the authorisation has changed not 
only the manner in which people are appointed, but also how their authority is established.

Earlier in this paper reference was made to Peter Skalník. According to him, much political struggle is concerned with finding a balance between authority and power. From the discussion of the essay by Friedman, it was seen that the field of social control consists of a wider range of concepts: those mentioned here have been authority, legitimised power, power, persuasion. In addition, it can be strongly argued that much change and political development seems to be a question of reaching an agreement on how these concepts are to be balanced in social life.

In the case of the reconciliation councils of Upper Egypt, the introduction of the mahdar tafwid into the process is in line with a range of developments in Egyptian society, because the change in the way the councils are set up also reveals changes in the authority structures. Today, there seems to be a trend towards using the practice of authorisation, thereby putting some people into positions of authority in ways that were not common in earlier times. Although the above discussion indicates that there is a wide range of methods to ensure that the solutions found by the arbitrators of the councils of Upper Egypt are followed, a primary one being the possibility of levying a fine on a party who may not follow the solution reached by the council, and persuading the parties to accept a solution - something that points towards legitimate power, and not to authority in the strict sense - this may be seen as just one more layer of means added from the field of social control.

What is important is that the members of the councils are appointed, and given an authority that contains specific preconditions to ensure a greater degree of equality, and also the possibility of replacing those sitting on the councils. They therefore represent a form of authority where the central point is that they issue a command to be followed, and not one to be believed - a difference that clearly indicates that the changing conditions in Egypt have influenced the working of the councils.

For those sitting on the councils the situation has also changed, because they are appointed to them through the authorisation, and in order to establish their position they no longer have to refer to their seniority, or their position within the tribal system, or that they hold specific political positions. They are members and have authority because they are appointed, and not because some other structure of power or authority is invoked.

58 It has been suggested (Alrabaa, 1986) that traditional forms of arbitration are losing influence among the younger generation because of their autocratic and old-fashioned forms of argument, as well as the ways in which their authority is created. As a result of education and exposure to new forms of social affiliation, younger people have become accustomed to and are in favour of a more combative form of communication. In the councils described here, there is no tendency for those having cases settled by the council to be from an older generation. The council members themselves are usually older men, but this is because their experience and knowledge is demanded by those in charge. Furthermore, acting as an arbitrator is very time-consuming, carrying the responsibility of attending numerous meetings, and often requiring much time to be spent arranging for the proper documentation to be in place, which may involve meetings with officials, etc. To many arbitrators, and especially those who are normally chosen to be council leaders, the role of arbiter can become a full-time profession. 

argumentative form, something clearly observable in that segment of the disputesettling process where the parties and witnesses are questioned. This may be difficult to accept for older shaykhs or religious figures, who find that their authority may be challenged by self-confident youngsters or by people whose position in the social hierarchy does not usually allow them to be outspoken in the presence of older shaykhs. With the use of the authorisations, this is in principle not a problem, since the members of the councils are there because they are appointed and authorised, and the validity of their authority, power or argument is therefore limited, as it is clearly indicated where and in which situations their statements can be authoritative.

Another important point is that those arbitrating do not have to ensure that the parties involved believe that they are in touch with any higher power when finding a solution to the dispute. Their solution is one that should followed up by action, and not one that should necessarily be believed. As the threat of chaos in the local community was given as a reason for people to accept someone being in authority and the procedures for appointing a council may be seen as "an elaborated contrivance designed to achieve agreement at the procedural level in face of disagreement at the substantive level..." (Friedman, 1990:78). That is, the parties agree to the procedures, to the appointment of the council and deference to its rulings, in order to solve problems occurring on the substantive level; after the mahdar tafwid has been signed it is time for action!

\section{BIBLIOGRAPHIE}

AlrabAa S., 1986, “Arbitration Discourse in Folk-Urban Egypt”, Cultures populaires. Peuples méditerranéens, 34, January-March.

Ammar, H., 1966,1954: Growing up in an Egyptian Village. Silwa, Province of Aswan, Londres, Routledge \& Keagan Paul.

ARENDT H., 1958: “What was Authority”, in Friedrich, Carl J. (ed.), Nomos 1. Cambridge, MA, Harvard University Press.

BEN NÉFISSA S., 1999, “The Haqq al-“Arab. Conflict Resolution and Distinctive Features of Legal Pluralism in Contemporary Egypt” (pp. 145-158), in Dupret, Baudouin, Maurits Berger and Laila al-Zwaini, Legal Pluralism in the Arab World. The Hague: Kluwer Law International.

Bourdieu P., 1977, Outline of a Theory of Practice, Cambridge: Cambridge University Press.

DuPRET B., 1999, “Legal Pluralism, Normative Plurality, and the Arab World” (pp. 2940), in Dupret, Baudouin, Maurits Berger and Laila al-Zwaini, Legal Pluralism in the Arab World, The Hague, Kluwer Law International.

Flathman R. 1980, The Practice of Political Authority. Authority and the Authoritative, Chicago, IL, University of Chicago Press.

Égypte/Monde arabe, 1 | 2005 
Friedman, Richard B., 1990, “On the Concept of Authority in Political Philosophy”, in Raz, Joseph (ed.), Authority. New York: New York University Press.

HANAFI H., 2002, “Alternative Conceptions of Civil Society: A Reflective Islamic Approach”, in Chambers, Simone and Will Kymlicka (eds), Alternative Conceptions of Civil Society. Princeton, NJ: Princeton University Press.

HART H. L. A., 1990, “Commands and Authoritative Legal Reasons”, in Raz, Joseph (ed.), Authority. New York, New York University Press.

KHALÎFAH AL-'ABÂDÎ,HASSAN AHMAD HUSAYN, 1940, Fi-l-saharâ'al-sharqiyya wa sharq al-sûdân: al-'Abâbda wa qabâ'il ukhrâ. Berber, Sudan.

Korsholm Nielsen H. C., 1998, "Men of Authority Documents of Authority: Notes on Customary Law in Upper Egypt" (pp. 357-370), in Hopkins, Nicholas S. and Kirsten Westergaard (eds), Directions of Change in Rural Egypt. Cairo: AUC Press.

-, 1998, "Négociation et écriture: à propos du droit coutumier en Haute Égypte" (pp.155-168), Égypte/Monde arabe, no. 34, 2e sem. 1998, Le Caire: CEDEJ.

-, (forthcoming), "State Law and Customary Law in Upper Egypt", Islamic Law and Society Revue Lawson S., 1997, "The Tyranny of Tradition: Critical Reflections on Nationalist Narratives in the South Pacific", in Otto, Ton and Nicholas Thomas (eds), Narratives of Nation in the South Pacific. Amsterdam: Harwood Academic Publishers.

LuKES S., 1990, “Perspectives on Authority”, in Raz, Joseph (ed.), Authority. New York: New York University Press.

Norton A. R., 1999, “The New Media, Civic Pluralism, and the Slowly Retreating State”, in Eickelman, Dale F. and Jon. W. Anderson (eds), New Media in the Muslim World. The Emerging Public Sphere. Bloomington: Indiana University Press.

Raz J., 1990, “Authority and Justification”, in Raz, Joseph (ed.), Authority. New York: New York University Press.

SKALNIK P., 1999, “Authority versus power: a view from social anthropology", in Cheater, Angela (ed.), The Anthropology of Power. Empowerment and Disempowerment in Changing Structures. ASA Monograph 36. London: Routledge \& Kegan Paul.

WALzER M., 2002, "Equality and Civil Society”, in Chambers, Simone and Will Kymlicka (eds), Alternative Conceptions of Civil Society. Princeton, NJ: Princeton University Press.

WEBER M., 1978, Economy and Society. An Outline of Interpretive Sociology (Roth, Guenther and Claus Wittich, eds). Berkeley: University of California Press.

\section{NOTES}

1. For other variations on the theme, see Hans Chr. Korsholm Nielsen (1998a, 1998b, and forthcoming)

2. First published in 1973.

3. With the limitations mentioned above.

4. The concept of "surrender of private judgement" has caused dispute since it was "reintroduced" by Friedman in his article from 1973; see for example Joseph Raz (1990:115-141) Steven Lukes (1990:203-217) and Richard Flathman (1980) - the latter being the most thorough. 
5. In this, there are of course similarities to the (too) often used concept of doxa presented by Bourdieu, and also to the orthodox and heterodox beliefs, the latter "implying awareness and recognition of the possibility of different or antagonistic beliefs" (1977:164).

6. Stephanie Lawson discusses the relevance of Friedman's concept of "traditional authority" for anthropology, in her article The Tyranny of Tradition: Critical Reflections on Nationalist Narratives in the South Pacific (1997:15-32).

7. What justifies the in authority may be some very pragmatic or utilitarian considerations. For Richard Flathman, this is one of the main reasons for opposing the concept of surrender of private judgement, because he finds that it is not justified - in the sense that one may be supportive of the existence of authority in modern society. He writes: "On this view of the matter the production of such goods provides authority with the same kind of justification that a system of slavery receives when the masters are benevolent enough to accord various benefits to their slaves. From an existential (as opposed to a principled) perspective, this may be no insignificant matter. Under circumstances that have been all too common in human affairs it may be the only matter of existential significance to the slaves or to the slave-like subjects of those masters. The argument can hardly pass muster as a principled defence of the practice of authority" (1980:222). He himself only sees authority justified if it enhances human agency, something that he finds is contradictory to a concept of surrender of judgement. One may agree, but on the other hand, it can be said that it is not necessarily so that the surrender of judgement is causing a limitation in agency - it may even be necessary to subject oneself to authority for a certain period in order to await the possibility of acting. But see below.

8. This specific presupposition (should) legitimise a position where one finds that authority relations may be justified, for example towards a position of "philosophical anarchism".

9. In the tradition in which Friedman (partly) writes, the concept of authority is often treated as a normative universalistic concept, but here Friedman clearly moves away from other writers such as Joseph Raz (op.cit.) and Hart (1990:92-114). For a discussion of Raz's position (and that of Friedman), see Steven Lukes (op.cit.).

10. That the councils are able to adjust is certainly not the only reason for the continuing importance of the non-state councils. These institutions are an integral part of Upper Egyptian life, and multiple layers of meanings and functions are ascribed to them. Some authors, however, are pointing in very different directions (see H. C. Korsholm Nielsen, forthcoming).

11. See Alrabaa (1986:65-87) for descriptions of these from the popular quarter of Bulaq in Cairo.

12. For more details about this differentiation between the different levels of conflict and the councils pertaining to them, see H. C. Korsholm Nielsen, 1998.

13. Their importance for Upper Egyptian society cannot be overstated, but it important to remember that these do not exist in a vacuum, but alongside the legal institutions of the state, with which they interact.

14. These two examples of documents are chosen out of a collection of around two hundred pertaining to the reconciliation councils of the Edfu area, collected between 1995 and 2001. The collection mainly contains documents finalizing disputes, settling inheritance issues, "authorisations" - and complaints submitted to the official authorities in cases where a party has felt that the solution reached by a council has not been correct, etc. 
INDEX

Mots-clés : assemblées d'arbitrage, autorité, droit, société civile

\section{AUTEUR \\ HANS CHRISTIAN KORSHOLM NIELSEN}

Université de Aarhus (Danemark) 